\title{
Calcein staining of calcified structures in pearl oyster Pinctada margaritifera and the effect of food resource level on shell growth
}

\author{
Clémentine Linard ${ }^{a, c}$, Yannick Gueguen ${ }^{b}$, Jacques Moriceau ${ }^{a}$, Claude Soyez $^{a}$, Bélinda Hui ${ }^{a}$, \\ Aurore Raoux ${ }^{a}$, Jean Pierre Cuif ${ }^{d}$, Jean-Claude Cochard ${ }^{a}$ e ${ }^{\text {, Marcel Le Pennec }}{ }^{c}$ \\ and Gilles Le Moullac ${ }^{a, *}$
}

\footnotetext{
a Ifremer, Laboratoire de Domestication de l'Huître Perlière, Centre Océanologique du Pacifique, Tahiti, BP 7004, 98719 Taravao, Tahiti, Polynésie française

b Ifremer, Laboratoire de Biotechnologie et Qualité de la Perle, Centre Océanologique du Pacifique, Tahiti, BP 7004, 98719 Taravao, Tahiti, Polynésie française

c Laboratoire Biodiversité Terrestre et Marine, UMR CNRS EA4239, Université de la Polynésie

Française, BP 6570, 98702 Faa'a, Tahiti, Polynésie française

d Laboratoire Interactions et Dynamique des Environnements de Surface, UMR 8148-IDES, Université Paris XI, Orsay, France

e Ifremer, Département Environnement Littoral et Ressources Aquacoles, Brest, Technopole de BrestIroise, BP 70, 29280 Plouzané, France
}

\author{
*: Corresponding author. Tel.: +689 546006; fax: +689 546099. \\ 20 E-mail address: Gilles.Le.Moullac@ifremer.fr
}

\begin{abstract}
:
Marine mollusc shell growth has been widely measured using fluorochrome marking. In order to test the efficiency and reliability of calcein staining on Pinctada margaritifera shells and pearls, the present study examined two administration methods, different concentrations and several immersion times. Immersion in a $150 \mathrm{mg} \mathrm{L}-1$ calcein solution for $12 \mathrm{~h}$ to $24 \mathrm{~h}$ appeared to be the best method for marking P. margaritifera shells. For pearl marking, injection of a $200 \mathrm{mg} \mathrm{L}-1$ calcein solution into the pearl pouch was the optimal method. Calcein marking was then used to measure the influence of food resource levels on the shell growth. Groups of 23-month-old P. margaritifera were fed at three trophic levels for two months. The two highest food levels tested (6000 cell mL-1 and 15000 cell $\mathrm{mL}-1$ ) induced uniform growth between the dorsal and ventral sides of shell, whereas the lowest food level (800 cell $\mathrm{mL}-1$ ) induced greater growth on the dorsal side. Shell deposits from the ventral side were observed using a scanning electron microscope, revealing that the difference of the trophic level over two months had modified the thickness of the aragonite tablets formed. These results showed that the trophic level is a major factor conditioning P. margaritifera development.
\end{abstract}

Keywords: Bivalvia; Pearl; Shell; Growth; Scanning electron microscope 


\section{ABSTRACT}

Marine mollusc shell growth has been widely measured using fluorochrome marking. In order to test the efficiency and reliability of calcein staining on P. margaritifera shells and pearls, the present study examined two administration methods, different concentrations and several immersion times.Immersion in a $150 \mathrm{mg} . \mathrm{L}^{-1}$ calcein solution for $12 \mathrm{~h}$ to $24 \mathrm{~h}$ appeared to be the best method for marking $P$. margaritifera shells. For pearl marking, injection of a $200 \mathrm{mg} . \mathrm{L}^{-1}$ calcein solution into the pearl pouch was the optimal method. Calcein marking was then used to measure the influence of food resource levels on the shell growth. Groups of 23-month-old P. margaritifera were fed at three trophic levels for two months. The two highest food levels tested (6 000 cell. $\mathrm{mL}^{-1}$ and 15000 cell. $\left.\mathrm{mL}^{-1}\right)$ induced uniform growth between dorsal and ventral sides of shell, whereas the lowest food level (800 cell.mL ${ }^{-1}$ ) induced greater growth on the dorsal side. Shell deposits from the ventral side were observed using a scanning electron microscope, revealing that the difference of trophic level over two months had modified the thickness of the aragonite tablets formed. These results showed that trophic level is a major factor conditioning $P$. margaritifera development.

\section{Key words: Bivalvia, pearl, shell, growth, scanning electron microscope}

\section{INTRODUCTION}

The black-lip oyster, Pinctada margaritifera cumingi, Linnaeus 1958 (Class: Bivalvia, Order: Pterioida, Family: Pteriidae), is used for the production of black pearls, and ranks among the most important commercial species in French Polynesia (Tisdell and Poirine 2000). Annual pearl production has increased from about $100 \mathrm{~kg}$ to more than $8000 \mathrm{~kg}$ within the last 20 years, with an annual turnover of about US\$170 million. This activity represents the second most important industry in French Polynesia after tourism. The main production sites are located in the Tuamotu-Gambier archipelago, where they represent the principal source of income for a quarter of local Polynesian families.

French Polynesia has the advantage of possessing natural stocks of these pearl oysters, which produce large numbers of larvae. Pearl oyster spat are commonly collected with lightweight spat collectors made from plastic mesh. Spat collectors are generally deployed for around 2 years and the pearl oysters are harvested when they attain a dorso-ventral shell height of approximately 50-65 mm (Cœroli et al. 1984, Pouvreau and Prasil 2001). Pteriidae shells grow by the deposition of layers of carbonate crystals and organic matrix. The shell is usually externally covered by a tanned protein sheet, "the periostracum”. Within the periostracum, a 
layer made up of calcite prisms, "the prismatic layer", is commonly described. There is then an internal layer composed of parallel aragonite tablets, "the nacreous layer" (Wilbur and Saleuddin 1983). Growth is a variable that depends on both the genetic basis of traits under selection and the impact of the environment (Nasr 1984, Gervis and Sims 1992, Sims 1993, 1994). Genotype-by-environment interactions dictate the final phenotype, and evidence of such interactions has been recently been demonstrated for the Pinctada genus (Kvingedal et al. 2008, Gu et al. 2009). Age, nursery culture methods, predator composition and abundance, and degree of fouling are all factors that can affect shell growth (Gervis and Sims 1992,

Taylor et al. 1997, Southgate and Beer 2000). The principal environmental factors influencing growth in most polar, temperate and tropical species are food availability, nutritional value of microalgae and temperature (Honkoop et Beukema 1997, Lodeiros et al. 1998, Laing 2000, Pouvreau et al. 2000a, 2000b, Yukihira et al. 1998b, 1999, 2000, Ahn et al. 2003). Despite the economical importance of this species, the impact of the environment on shell and pearl growth of $P$. margaritifera remains poorly understood.

In order to measure growth of calcified structures, several techniques have already been used. For example, shell growth has been assessed through shell length, shell height or shell width measurements (Pouvreau et al. 2000a, Hwang et al. 2007). However, external size quickly becomes a poor indicator of growth and age because growth rate varies among individuals and according to reproductive status (Pouvreau 1999). External measurements may therefore lead to biased growth estimations. Other studies have investigated shell perforation, sawing and emersion as methods to measure $P$. margaritifera shell growth during a known period (Caseiro 1993). However, these methods are likely to disrupt normal growth, as they cause physical damage (Caseiro 1993). Fluorochrome dyes have been used to validate growth checks (Day et al. 1995, Hales and Hurley 1991) and to investigate the layer formation pattern (Nakahara, 1961, Rowley and Mc Kinnon 1995, Schöne et al. 2003). These chemical stains bind to calcium and are incorporated into newly mineralizing shell, producing an internal growth mark that can thus subsequently be used for the analysis of environmental effects on short term growth rates (Nakahara, 1961, Schöne et al. 2003). Calcein is a fluorochrome that is easy to use and to detect and has been widely tested as growth marker for many marine animals, including bivalves, gastropods (Day et al. 1995, Rowley and McKinnon 1995, Kaehler and McQuaid 1999, Moran 2000, Eads and Layzer 2002, Moran 2005, Thébault et al. 2006, Riascos et al. 2007, Lucas et al. 2008).

In this study, a protocol using calcein fluorescent marking was developed to measure $P$. margaritifera shell and pearl growth. Calcein staining efficiency was assessed comparing 
different administration methods, concentrations and immersion times, and the protocols were then used to investigate shell and pearl growth. Shell growth was described and measured on the ventral and dorsal sides and the influence of food abundance on the shell growth variability was examined and quantified. Furthermore, the influence of the food resources on the structure of the aragonite tablets, which compose the nacreous layer of the shell, was examined using scanning electron microscopy.

\section{MATERIAL AND METHODS}

\subsection{Chemicals}

Calcein was purchased from Sigma Aldrich, France. The stain powder was dissolved over $12 \mathrm{~h}$ at $24{ }^{\circ} \mathrm{C}$ in filtered $(0.1 \mu \mathrm{m})$ seawater using a magnetic stirrer. The following concentrations were prepared: 50, 100, 150 and 200 mg.L ${ }^{-1}$. Calcein administration techniques, concentrations and immersion periods were tested (Table 1).

\subsection{Calcein shell marking}

The efficacy of calcein for marking shells was tested on 10 -month-old pearl oysters $(\mathrm{N}=84$, shell length average: $35 \pm 0.02 \mathrm{SD} \mathrm{mm})$ produced in the Ifremer hatchery in Vairao $\left(17^{\circ} 48^{\prime} \mathrm{S}\right.$, $149^{\circ} 17^{\prime}$ O) Tahiti, Society archipelago, French Polynesia. Shell marking was performed either by injection or immersion. For the injections, two concentrations of calcein (50 and $100 \mathrm{mg} . \mathrm{L}$ ${ }^{1}$ ) were tested on $P$. margaritifera pearl oysters (N=3/condition). Calcein was introduced using a sterile syringe inserted through the byssus hole into the palleal cavity until the cavity was filled with marker solution. Care was taken to insert the needle without injuring the pearl oyster. Animals were placed between wet towels for 30-40 min before returning them to $25-\mathrm{L}$ tanks in an open seawater circulation system (120 L.h ${ }^{-1}$ water turnover). Seawater temperature was measured and seen to remain around $28 \pm 0.3 \mathrm{SD}{ }^{\circ} \mathrm{C}$. For the immersion protocol, three calcein concentrations (50, 100 and $\left.150 \mathrm{mg} . \mathrm{L}^{-1}\right)$ were tested in 3-L aquaria. For each concentration, samples of three pearl oysters were taken after $6 \mathrm{~h}, 12 \mathrm{~h}$ and $24 \mathrm{~h}$ immersion time. A control batch was also kept under the same conditions but without calcein treatment, to evaluate toxicity of the stain. Calcein immersions were realized in aquaria equipped with an aerated sea water system and protected from light. During immersion, no water changes were made. After immersion and injection trials, the $P$. margaritifera pearl oysters were reared in 25-L tanks. Seawater $\left(27^{\circ} \mathrm{C}\right)$ was renewed 4 times per hour. A diet of 10000 algal cell $\mathrm{mL}^{-1}$, composed of a 2:1 mix of Isochrysis galbana (T-Iso) and Chaetoceros gracilis cells 
was supplied continuously. Marking success was evaluated two months later. To investigate ventral marking, shells were sawn according to the third section shown in Fig. 1.

\subsection{Dynamics of shell growth}

To explore shell growth dynamics, fifteen 40-month-old $P$. margaritifera pearl oysters (mean shell length: $122 \pm 13.8 \mathrm{SD} \mathrm{mm}$ ) shipped from the Takapoto atoll $\left(14^{\circ} 41^{\prime} \mathrm{S}, 145^{\circ} 14^{\prime} \mathrm{O}\right.$, Tuamotu archipelago, French Polynesia) were used. Two marking of pearl oysters were carried out at an interval of two months. The first and the second marking were done in similar conditions by immersion in a $150 \mathrm{mg} . \mathrm{L}^{-1}$ calcein solution in 3 -L aquaria during $24 \mathrm{~h}$. Between the two marking, the pearl oysters were reared in lagoon. To explore shell growth with respect to anterior, ventral, posterior, dorsal and central parts of the shell, samples were sawn eight times, from the umbo to the growing edge, to obtain nine parallel shell pieces (Fig. 1). Anterior and posterior pieces were then sawn three more times, perpendicular to the section axis. Growth of the prismatic and nacreous shell layers was studied by examining 12 prismatic points and 35 nacreous points on each shell (Fig. 1).

\subsection{Influence of trophic level on shell growth}

In this experiment, 23-month-old pearl oysters ( $\mathrm{N}=60$, mean shell length: $85 \pm 5.7 \mathrm{SD} \mathrm{mm})$ were firstly put into three $500-\mathrm{L}$ seawater tanks $(\mathrm{N}=20 /$ tank) equipped with an open sea water circulation system (water renewal of $96 \mathrm{~L} . \mathrm{h}^{-1}$ ) and acclimatized over two weeks before the staining was performed and the diet treatments started. The $P$. margaritifera pearl oysters were then submitted to a $150 \mathrm{mg} . \mathrm{L}^{-1}$ calcein immersion for $24 \mathrm{~h}$. Three level were tested : 800 cell.mL $\mathrm{m}^{-1}, 6000$ cell. $\mathrm{mL}^{-1}$ or 15000 cell. $\mathrm{mL}^{-1}$ composed of a microalgae mix (Isochrysis aff. galbana, and Chaetoceros aff. gracilis, v:v) continuously supplied for two months. The mean temperature of seawater during this experiment was $29.4 \pm 0.2 \mathrm{SD}{ }^{\circ} \mathrm{C}$ Mortalities were recorded during the experiment. Ten specimens per treatment were collected after the first month of experimentation and ten more, one month later. To investigate ventral and dorsal growth, shells were sawn at the third section shown in Fig. 1.

\subsection{Calcein pearl marking}

To mark pearls, two grafted adult populations aged 40 months (mean shell length: 122 $\pm 13.8 \mathrm{SD} \mathrm{mm})$ shipped from the Takapoto atoll were used. The first population $(\mathrm{N}=27)$ was grafted four months before the staining experiment and the second one $(\mathrm{N}=22)$, twenty-four months before the staining experiment. Both injection and immersion methods were tested. 
149 For the injection method, $1 \mathrm{~mL}$ of the calcein solution was introduced into the pearl pouch

150 using a sterile syringe. Two concentrations of calcein were tested: 150 and $200 \mathrm{mg} . \mathrm{L}^{-1}$. The immersion staining protocol was the same as that described above for shell marking and the same calcein concentrations were tested as with the injection method (150 and $\left.200 \mathrm{mg} . \mathrm{L}^{-1}\right)$. Double marking was carried out at a two-month interval for both groups of grafted specimens. Consequently, at the end of experimentation, pearls were aged six months in the first batch and twenty-six months in the second batch. The grafted pearl oysters were reared in $25-\mathrm{L}$ tanks in same conditions described in section 2.2. Marking efficiency and pearl growth were evaluated two months later. Pearls were incorporated into a wax block before being sawn transversally.

\subsection{Calcein detection}

The shells and the pearls were sawn using a "Swap Top Trim Saw" machine (Inland, Middlesex, United Kingdom), which includes a diamond Trim Saw Blade (Thin Cut) IC40961. Shell and pearl edges were then polished for $5 \mathrm{~s}$ with various grades of water sandpaper sheet. The shell and pearl sections were then examined under a Leitz Dialux 22 compound fluorescence microscope equipped with a I3 filter block and an optical micrometer. To determine calcein marking success on shell and pearls, calcein was recorded in the prismatic and/or nacreous layers using a binary system (1: mark; 0: no mark). Then, to measure shell and pearl growth, increments deposited between the two calcein marks were measured using an optical micrometer (Fig. 2).

\subsection{Shell deposit structure}

The structure of the shell deposit was observed by scanning electron microscopy (SEM). Pearl oyster shells were sawn at the third section shown in Fig. 1. The ventral side of the shells was isolated, embedded in resin and polished using various grades of diamond paste, down to a final $0.25 \mu \mathrm{m}$ grade. To reveal microstructural features, polished shell sections were etched for $40 \mathrm{~s}$ with a formic acid solution (1\%) mixed with glutaraldehyde (3\%). SEM observations were conducted using a Philips XL30 instrument housed at the Laboratoire Interactions et Dynamique des Environnements de Surface, Orsay, France.

\subsection{Statistical analysis}

In order to evaluate marking efficiency according to the different administration methods (injection $v s$. immersion), calcein concentration and immersion times, $\mathrm{Khi}^{2}$ tests or 
180 Fisher tests were realized using XLSTAT software 2007.7 (Bouyer 1996, Scherrer 1984).

181 Nacreous deposits were square root transformed to normalize data distribution and a one-way 182 ANOVA was performed to compare nacreous deposition between the dorsal and ventral side 183 of the shell. Effect of trophic level on shell growth on the ventral and dorsal sides was 184 analysed using a two way ANOVA following by a PLSD Fisher test using Statview version 1855.0 software. Square root transformed pearl deposit on 4 and 24 month-old pearls was 186 compared using the Student t test.

\section{RESULTS}

\subsection{Optimization of shell and pearl marking}

189 For both shell and pearl marking experiments, no mortality caused by calcein staining was

190 recorded on the $P$. margaritifera pearl oysters. Shell marking frequency was significantly different according to the administration method. Using the immersion method, $85 \%$ of the shells were marked, whereas only $35 \%$ of the shells were marked after calcein injection into the palleal cavity $\left(\mathrm{Khi}^{2}=17.211 ; \mathrm{df}=1 ; \mathrm{p}<0.0001\right)$ (Fig. 3a). Calcein concentration also significantly influenced the shell marking frequency (Fisher test; $\mathrm{p}=0.012$ ). After immersion in a $150 \mathrm{mg} . \mathrm{L}^{-1}$ calcein solution, $100 \%$ of $P$. margaritifera shells were marked. After immersion in 50 and $100 \mathrm{mg} . \mathrm{L}^{-1}$, calcein solutions, only $65 \%$ and $89 \%$ of shells were marked, respectively (Fig. 3b). An effect of immersion time was also observed. Shell marking frequencies were significantly higher for $12 \mathrm{~h}$ and $24 \mathrm{~h}$ than for $6 \mathrm{~h}$ immersion (Fisher test; $\mathrm{p}=0.023)($ Fig. 3c).

For pearl marking, the injection of calcein into the pearl pouch showed double the efficiency of the immersion method ( $88 \%$ vs. $43 \%)\left(\mathrm{Khi}^{2}=16.67 ; \mathrm{df}=1 ; \mathrm{p}<0.0001\right)$ (Fig. 4a). Furthermore, the concentration of calcein significantly influenced the pearl marking frequency $\left(\mathrm{Khi}^{2}=5.10 ; \mathrm{df}=1 ; \mathrm{p}=0.024\right)$, using a $200 \mathrm{mg} . \mathrm{L}^{-1}$ calcein concentration delivered by injection, $100 \%$ of the pearls were marked whereas only $75 \%$ of pearls were marked at 150 mg. $\mathrm{L}^{-1}$ (Fig. 4b). In addition, pearl age significantly influenced calcein incorporation: $97 \%$ of the 4 month-old pearls were marked, while only $36 \%$ of 24 month-old pearls were marked $\left(\mathrm{Khi}^{2}=6.41 ; \mathrm{df}=1 ; \mathrm{p}=0.011\right)$, for all treatments combined.

\subsection{Dynamics of shell growth}

Shell growth was measured using calcein fluorochrome marks on 15 shells of $P$. margaritifera, each sawn into eight sections (Fig. 1). The thickness measurements of the 
prismatic and nacreous deposits at the anterior, ventral and posterior area of the shells were not significantly different $(\mathrm{F}=1.07 ; \mathrm{df}=1 ; \mathrm{p}=0.3031)$. After two months of growth, shell deposit rate at the nacreous layer of the dorsal side measured 5.12 $\pm 4.36 \mathrm{SD} \mu \mathrm{m}_{\text {.day }}{ }^{-1}$, whereas shell deposit rate at the nacreous layer for the anterior, ventral and posterior sides were significantly lower $\left(3 \pm 2.13 \mathrm{SD} \mu\right.$ m.day $^{-1}, 2.88 \pm 2.53 \mathrm{SD} \mu$ m.day $^{-1}, 2.76 \pm 1.92 \mathrm{SD}$ $\mu \mathrm{m}$. day $^{-1}$, respectively) (Fig. 5). The difference observed for the dorsal part compared to the anterior, ventral and posterior area is significant $(\mathrm{F}=2.78 ; \mathrm{df}=3 ; \mathrm{p}=0.0458)$. No calcein mark was detected in the central area of the shell. Hence, shell growth could only be observed at the perimeter of the valves.

\subsection{Shell growth is correlated with trophic level}

To evaluate the influence of food resources on P. margaritifera shell growth, 3 microalgal diets were tested over two months. Shell deposition on the ventral and dorsal sides was significantly higher for the 15000 cell. $\mathrm{mL}^{-1}$ diet than for the 6000 cell. $\mathrm{mL}^{-1}$ one, and significantly higher for the 6000 cell. $\mathrm{mL}^{-1}$ diet than for the 800 cell. $\mathrm{mL}^{-1}$ one (Fig. 6) $(\mathrm{F}=22.14 ; \mathrm{df}=2 ; \mathrm{p}<0.0001)$.

Differences between ventral and dorsal growth depended on diet $(F=10.50 ; d f=1 ; p<0.0017)$. For the 800 cell. $\mathrm{mL}^{-1}$ diet, dorsal nacreous increment was significantly higher than ventral nacreous increment ( $\mathrm{p}=0.0001$ ) (Fig. 6). The dorsal growth rate was about $6.3 \pm 3.0 \mathrm{SD}$ $\mu$ m.day ${ }^{-1}$ whereas ventral growth rate was about $2.6 \pm 1.3 \mathrm{SD} \mu \mathrm{m}$.day ${ }^{-1}$. In contrast, no significant differences between ventral and dorsal sides were detected at 6000 cell.mL $\mathrm{m}^{-1}$ $(\mathrm{p}=0.3072)$ or at 15000 cell. $\mathrm{mL}^{-1}(\mathrm{p}=0.2042)$.

\subsection{Influence of trophic level on aragonite tablet thickness}

233 The present study demonstrated that shell increment on the ventral side is greater for higher

234 food level than for lower food level. Following the lowest and highest diets $\left(800\right.$ cell.mL ${ }^{-1}$ 235 and 15000 cell. $\mathrm{mL}^{-1}$ ), shell deposit structure on the ventral side of $P$. margaritifera pearl oyster was observed by SEM. Observations showed that the food level seemed to act on the aragonite tablet thickness of the shell. Observations showed that during the two months of the experiment, the thickness of the aragonite tablets of the shell reduced with time whatever the food level considered. Aragonite tablets deposited just after calcein staining looked thicker than the later aragonite tablets deposited at the end of the experiment (Fig. 7 a, b, c, d).

When a section of identical thickness was compared between shells of pearl oysters

242 from the different diet treatments at the start and end of the experimental period, two 
differences were observed in the aragonite tablets. In the initial stage of the experiment, the number of aragonite tablets composing a $10 \mu \mathrm{m}$ section was lower in oysters from the higher food treatment $(\mathrm{N}=13)$ than in those from the lower food treatment $(\mathrm{N}=17)$ (Fig. $7 \mathrm{~b}, \mathrm{c})$. Indeed, aragonite tablets were thicker in the higher food treatment. At the end of the experiment, the opposite trend was recorded: the number of aragonite tablets in a $10 \mu \mathrm{m}$ section was higher for the higher food level $(\mathrm{N}=20$ for the lower food level, $\mathrm{N}=21$ for the higher food level) (Fig. 7 a, d). At the end of the experimental period, therefore, aragonite tablets of the shell in oysters fed at the lower food level were thicker than those in shells of oysters fed at the higher food level.

\subsection{Pearl growth analyses}

Pearl growth rate was evaluated at two points after the graft. Pearl growth rate was significantly higher for 4 month-old pearls than for 24-month-old pearls $(\mathrm{p}=0.0002)$ (Fig. 8). Pearl growth rates were $1.44 \pm 0.04 \mathrm{SD} \mu \mathrm{m}_{\text {.day }}{ }^{-1}$ for the 4-month-old pearls and $9.21 .10^{-2} \pm$ $0.01 \mathrm{SD} \mu \mathrm{m}$.day ${ }^{-1}$ for 24 -month-old pearls.

\section{DISCUSSION}

During recent decades, fluorochromes have attracted attention as they can serve to create a fluorescent line in calcified structures. In this study, calcein marking efficiency was investigated on $P$. margaritifera to measure shell and pearl growth and to evaluate the influence of food levels on the growth of these structures. In our study, no mortality due to calcein administration was recorded. Compared with other species, $P$. margaritifera, therefore, presented a good resistance to the calcein marking process (Day et al. 1995, Bumguardner and King 1996, Gelsleichter et al. 1997, Eads and Layzer 2002). Several administration methods, concentrations and immersion times were tested. The most efficient method for marking shells, was shown to be immersion of pearl oysters in $150 \mathrm{mg} . \mathrm{L}^{-1}$ calcein solution for 12 to $24 \mathrm{~h}$. Marking success increased with concentration and immersion time. Similar results have been obtained for other taxa: polychaete worms (Serpula columbiana), gastropods (Concholepas concholepas, Nucella ostrina), bivalves (Comptopallium radula, Mesodesma donacium) and fishes (Wilson et al. 1987, Brooks et al. 1994, Day et al. 1995, Rowley and Mc Kinnon 1995, Kaehler and Mc Quaid 1999, Moran 2000, Eads and Layzer 2002, Iyengar 2002, Thébault et al. 2006, Riascos et al. 2007). To mark pearls, injection into the pearl pouch clearly gave better results than immersion. Twice as many pearls were marked with the injection technique compared with the immersion method. Our results showed that 
275 all pearls were marked with injected calcein at $200 \mathrm{mg} \mathrm{L}^{-1}$ concentration.. Calcein marks have 276 been observed in shells as well as pearls up to one year after marking, demonstrating that 277 marks made in this way have a long-term life span. Riascos et al. (2007) noted a seven-month 278 life span in C. concholepas and M. donacium.

279 Using calcein marking, we followed the growth rate of three parts of the P. margaritifera 280 shell, the peripheral part, the dorsal part and the central part, which were shown to differ. 281 Disruptive shell growth has been evoked for many species (Day et al. 1995, Rowley and Mc 282 Kinnon 1995, Kaehler and Mc Quaid 1999). The peripheral part of the shell is composed of 283 anterior, ventral and posterior areas and has active bio-mineralization. Present results showed an active deposition rate for nacreous and prismatic layers, with similar deposition rate in the two. Secondly, the dorsal side of the shell was distinguished by a nacreous deposit rate 1.8 times higher than on the ventral side over the two-month study period. Lastly, the central part of the shell is defined by a fluorochrome-free area. To explain this fluorochrome-free area, two hypotheses can be proposed. Either, $24 \mathrm{~h}$ is not sufficient for calcein incorporation into the central area of the shell, or the measurement technique is not adapted to detecting the growth pattern of this area.

Physiological processes are affected by endogenous and exogenous factors. Exogenous factors include physical (temperature), chemical (oxygen, salinity) and biological (food availability) parameters, of which food resources are considered to be one of the most important (Nasr 1984, Sims 1993, Honkoop et Beukema 1997, Yukihira et al. 1998b, Laing 2000). Using calcein marking, we measured the impact of trophic level on ventral and dorsal shell growth in P. margaritifera. After the two-month experiment, the lowest food level clearly favored growth of the dorsal side of the shell over that of the ventral side. However, when micro-algal concentration was higher, shell growth increased and was equal between dorsal and ventral parts. Consequently, the highest shell deposits on ventral and dorsal sides were recorded at the highest food level. The positive influence of food resources on shell growth has also been demonstrated for mussel C. meridionalis and M. edulis (Griffiths 1980b, Bayne and Worrall 1980). Winter (1978) evocated an optimum food concentration beyond which growth rate declined. In our experiment, food optimum was not reached since no growth rate decline was observed when microalgae concentration rose. These results are in line with Yukihira et al. (1998b), who detected an optimal food concentration between 10000 cell. $\mathrm{mL}^{-1}$ and 20000 cell. $\mathrm{mL}^{-1}$ for $P$. margaritifera. Even though this bivalve is adapted to the oligotrophic lagoon waters of French Polynesian, our results show that P. margaritifera can also adapt itself to higher trophic levels. 
SEM observations of $P$. margaritifera shells differed according to trophic level simultaneously revealing a temporal evolution of mineralization rate and the influence of trophic level on aragonite tablet thickness. Shells of pearl oysters fed the highest food level had thicker aragonite tablets than those of pearl oysters fed the lowest food level.

313 Consequently, there seems to be a higher shell deposition rate in pearl oysters fed at the

314 highest food level due to a combination of thicker aragonite tablets and an increasing shell 315 deposit rate.

Plasticity and modification in growth expression due to genotype by environment interactions have already been demonstrated for the Pinctada genus (Kvingedal et al. 2008, $\mathrm{Gu}$ et al. 2009). Among endogenous parameters known to affect growth, age is presumably the most important. In the present study conducted in Vairao, Tahiti, the pearl growth rate for the 4-month-old pearls over a two month period was $1.44 \pm 0.04 \mu$ m.day $^{-1}$, and the pearl growth rate for 24 month-old pearls was $9.21 .10^{-2} \pm 0.01 \mu$ m.day ${ }^{-1}$. The pearl growth rate decreased by about 15 times between 4-month-old pearls and 24-month-old pearls. The influence of pearl age on pearl growth has been already studied in P. margaritifera in Takapoto until the 13th month after the grafting process, revealing a growth rate of $3.60 \pm$ $1.60 \mu$ m.day $^{-1}$ (Caseiro 1993). Takapoto and Vairao differ in temperature and chlorophyll-a concentration. Temperature in Takapoto ranks between $26.5^{\circ} \mathrm{C}$ and $30.5^{\circ} \mathrm{C}$ while temperature in Vairao ranks between $25^{\circ} \mathrm{C}$ and $29^{\circ} \mathrm{C}$. Buestel and Pouvreau (2000) found a chlorophyll-a concentration of about $0.28 \mu \mathrm{g} . \mathrm{L}^{-1}$ at depths between 8 and $10 \mathrm{~m}$, whereas chlorophyll-a concentration measured in Vairao lagoon in 2000 at a depth of $7 \mathrm{~m}$ was about $0.184 \mu \mathrm{g} . \mathrm{L}^{-1}$ (Pers. Comm. Le Moullac). These indications, coupled with the age of the pearls, may contribute to explaining pearl growth differences between those two sites.

Description of the impact of the environment on P. margaritifera shell growth is a valuable area of research because of the production challenge. French Polynesia is the top 334 exporter of cultured $P$. margaritifera black pearls in the world. The country is composed of more 115 islands with different environmental conditions. Maximizing growth rate of pearl oysters will reduce the time needed to rear them to operable size for the pearl grafting operation and, therefore, increase farm profitability. Temperature is another environmental factor of prime importance for growth in pearl oysters (Pandya 1976, Honkoop and Beukema 1997, Laing 2000, Yukihira et al. 2000, Tomaru et al. 2002, Saucedo et al. 2004, Gu et al. 2009), so we will examine its effects in our future research. 


\section{Acknowledgements}

342 This study is part of a collaborative project (GDR ADEQUA) supported by the "Service de la 343 perliculture" of French Polynesia. It is also supported by Ifremer and University of French 344 Polynesia. Authors are grateful to Marcel Le Pennec for helpful discussions and assistance. 345 Thanks also to Helen McCombie-Boudry for improving the English in this paper.

\section{References}

Ahn, I.Y., Surh, J., Park, Y.G., Kwon, H., Choi, K.S., Kang, S.H., Choi, H.J., Kim, K.W., Chung, H., 2003. Growth and seasonal energetics of the Antarctic bivalve Laternula elliptica from King George Island, Antarctica. Mar. Ecol. Prog. Ser. 257, 99-110.

Bayne, B.L., Worrall, C.M., 1980. Growth and production of Mussels Mytilus edulis from two populations. Mar. Ecol. Prog. Ser. 3, 317-328.

Bouyer, J., 1996. Méthodes statistiques-Médecine-Biologie, ed. INSERM, France.

Brooks, R.C., Heidinger, R.C., Kohler, C.C., 1994. Mass-Marking Otoliths of Larval and Juvenile Walleyes by Immersion in Oxytetracycline, Calcein, or Calcein Blue. N. Am. J. Fish. Manage. 14, 143-150.

Buestel, D., Pouvreau, S., 2000. Particulate matter in Takapoto lagoon waters: potential food for cultivated pearl oysters. Oceanol. Acta. 23, 193-210.

Bumguardner, B.W., King, T.L., 1996. Toxicity of oxytetracycline and calcein to juvenile striped bass. T. Am. Fish. Soc. 125, 143-145.

Caseiro, J., 1993. La Nacre noire de Polynésie: Bio-minéralisation, paramètres de croissance, effets chromatiques dans la coquille et la perle de Pinctada margaritifera. Thèse, Université Claude Bernard-Lyon I. 386pp.

Cœroli, M., De Gaillande, D., Landret, J.P., AQUACOP (Coatanea, D.), 1984. Recent innovations in cultivation of molluscs in French Polynesia. Aquaculture. 39, 45-67.

Day, R.W., Williams, M.C., Hawkes, G.P., 1995. A comparison of fluorochromes for marking abalone shells. Mar. Freshwater Res. 46, 599-605.

Eads, C.B., Layzer, J.B., 2002. How to pick your mussels out of a crowd: using fluorescence to mark 10 month-old oyster freshwater mussels. J. N. Am. Benthol. Soc. 21, 476-486.

Gelsleichter, J., Cortes, E., Manire, C.A., Hueter, R.E., Musick, J.A., 1997. Use of calcein as a fluorescent marker for elasmobranch vertebral cartilage. T. Am. Fish. Soc. 126, 862-865.

Gervis, M.H., Sims, N.A., 1992. The biology and culture of pearl oysters (Bivalvia: Pteriidae). ICLARM, Metro Manila, Philipines/ODA, London, England. 
Griffiths, R.J., 1980b. Natural Food Availability and Assimilation in the Bivalve Choromytilus meridionalis. Mar. Ecol. Prog. Ser. 3, 151-156.

Gu, Z.F., Wang, Q.Y., Fang, J., Ye, N.H., Mao, Y.Z., Shi, Y.H., Wang, Y., Wang, A.M., 2009. Growth of Cultured Pearl Oyster (Pinctada martensii) in Li'an Lagoon, Hainan Island, China. J. Shellfish Res. 28, 465-470.

Hales, L.S., Hurley, D.H., 1991. Validation of daily increment formation in the otolithsof juvenile silver perch, Bairdiella chrysoura. Estuaries. 14, 199-206.

Honkoop, P.J.C., Beukema, J.J., 1997. Loss of body mass in winter in three intertidal bivalve species: an experimental and observational study of the interacting effects between water temperature, feeding time and feeding behaviour. J. Exp. Mar. Biol. Ecol. 212, 277-297.

Hwang, J.J., Yamakawa, T., Aoki, I., 2007. Growth of wild pearl oysters Pinctada fucata, Pinctada margaritifera and Pinctada sugillata (Bivalvia: Pteriidae) in Taiwan. Fish. Sci. $73,132-141$.

Iyengar, E.V., 2002. Sneaky snails and wasted worms: kleptoparasitism by Trichotropis cancellata (Mollusca, Gastropoda) on Serpula columbiana (Annelida, Polychaeta). Mar. Ecol. Prog. Ser. 244, 153-162.

Kaehler, S., McQuaid, C.D., 1999. Use of the fluorochrome calcein as an in situ growth marker in the brown mussel Perna Perna. Mar. Biol. 133, 455-460.

Kvingedal, R., Evans, B.S., Taylor, J.J.U., Knauer, J., Jerry, D.R., 2008. Family by environment interactions in shell size of 43-day old silver-lip pearl oyster (Pinctada maxima), five families reared under different nursery conditions. Aquaculture. 279, 23-28.

Laing, I., 2000. Effect of temperature and ration on growth and condition of king scallop (Pecten maximus) spat. Aquaculture. 183, 325-334.

Lodeiros, C.J., Rengel, J.J., Freites, L., Morales, F., Himmelman, J.H., 1998. Growth and survival of the tropical scallop Lyropecten (Nodipecten) nodosus maintained in suspended culture at three depths. Aquaculture. 165, 41-50.

Lucas, T., Palmer, P.J., Wang, S., Scoones, R., O’Brien, E., 2008. Marking the shell of the saucer scallop Amusium balloti for sea ranching using oxytetracycline, calcein and alizarin red S. J. Shellfish Res. 27, 1183-1188.

Moran, A.L., 2000. Calcein as a marker in experimental studies newly-hatched gastropods. Mar. Biol. 137, 893-898.

Moran, A.L., 2005. A simple technique for physical marking of larvae of marine bivalves. J. Shellfish Res. 24, 567-571. 
Nakahara, H., 1961. Determination of growth rates of nacreous layer by the administration of tetracycline. Bull. natl. Pearl Res. Lab. 6: 607-614.

Nasr, D.H., 1984. Feeding and growth of the pearl oyster Pinctada margaritifera_L. in Dongonab Bay, Red Sea. Hydrobiologia. 110, 241-245.

Pandya, J.A., 1976. Influence of temperature on growth ring formation in the pearl oyster, Pinctada fucata (Gould) of the Gulf of Kutch. Indian J. Mar. Sci. 5, 249-251.

Pirker, J.G,. Schiel, D.R., 1993. Tetracycline as a fluorescent shell-marker in the abalone Haliotis iris. Mar. Biol. 116, 81-86.

Pouvreau, S., 1999. Etude des mécanismes expliquant la croissance de l'huître perlière Pinctada margaritifera au sein de l'écosystème conchylicole du lagon de l'atoll de Takapoto (Polynésie française). Thèse, Ecole Nationale Supérieure d'Agronomie de Rennes. 267pp.

Pouvreau, S., Tiapari, J., Gangnery, A., Lagarde, F., Garnier, M., Teissier, H., Haumani, G., Buestel, D., Bodoy, A., 2000a. Growth of the black-lip oyster, Pinctada margaritifera, in suspended culture under hydrobiological conditions of Takapoto lagoon (French Polynesia). Aquaculture. 184, 133-154.

Pouvreau S., Gangnery, A., Tiapari, J., Lagarde, F., Garnier, M., Bodoy, A., 2000b. Gametogenic cycle and reproductive effort of the tropical blacklip pearl oyster, Pinctada margaritifera (Bivalvia: Pteriidae), cultivated in Takapoto atoll (French Polynesia). Aquat. Living Resour. 13, 37-48.

Pouvreau, S., Prasil, V., 2001. Growth of the black-lip oyster, Pinctada margaritifera, at nine culture sites of French Polynesia: synthesis of several sampling designs conducted between 1994 and 1999. Aquat. Living Resour. 14, 155-163.

Riascos, J., Guzman, N., Laudien, J., Heilmayer, O., Oliva, M., 2007. Suitability of three stains to mark shells of Concholepas concholepas (Gastropoda) and Mesodesma donacium (Bivalvia). J. Shellfish Res. 26, 43-49.

Rowley, R.J., McKinnon, D.I., 1995. Use of the fluorescent marker calcein in biomineralisation studies of brachiopods and other marine organisms. Bulletin de l'institut océanographique, Monaco. 14.

Saucedo, P.E., Ocampo, L., Monteforte, M., Bervera, H., 2004. Effect of temperature on oxygen consumption and ammonia excretion in the Calafia mother-of-pearl-oyster Pinctada mazatlanica (Hanley, 1856). Aquaculture. 229, 377-387.

Scherrer, B., 1984. Biostatistique, ed. Gaëtan Morin, Montréal-Paris. 
Schöne, B.R., Tanabe, K., Dettman, D.L., Sato, S., 2003. Environmental controls on shell growth rates and delta $\mathrm{O}^{-18}$ of the shallow-marine bivalve mollusk Phacosoma japonicum in Japan. Mar. Biol. 142, 473-485.

Sims, N.A., 1993. Size, age and growth of the black-lip pearl oyster, Pinctada margaritifera (L.) (Bivalvia ; Pteriidae). J. Shellfish Res.12, 223-228.

Sims, N.A., 1994. Growth of wild and cultured black-lip pearl oysters, Pinctada margaritifera (L.) (Pteriidae, Bivalvia), in the Cook-Islands. Aquaculture. 122, 181-191.

Southgate, P.C., Beer, A.C., 2000. Growth of blacklip pearl oyster (Pinctada margaritifera) juveniles using different nursery culture techniques. Aquaculture. 187, 97-104.

Taylor, J.J., Southgate, P.C., Rose, R.A., 1997b. Fouling animals and their effect on the growth of silver-lip pearl oysters, Pinctada maxima (Jameson) in suspended culture. Aquaculture. 153, 31-40.

Thébault, J., Chauvaud, L., Clavier, J., Fichez, R., Morize, E., 2006. Evidence of a 2-day periodicity of striae formation in the tropical scallop Comptopallium radula using calcein marking. Mar. Biol. 149, 257-267.

Tisdell, C.A., Poirine, B., 2000. Socio-economics of pearl culture: Industry changes and comparisons focusing on Australia and French Polynesia. World Aquaculture. 11, 30-37, 58-61.

Tomaru, Y., Kumatabara, Y., Kawabata, Z., Nakano, S., 2002. Effect of water temperature and chlorophyll abundance on shell growth of the Japanese pearl oyster, Pinctada fucata martensii, in suspended culture at different depths and sites. Aquac. Res. 33, 109-116.

Yukihira, H., Klumpp, D.W., Lucas, J.S., 1998a. Effects of body size on suspension feeding and energy budgets of the pearl oysters Pinctada margaritifera and P. maxima. Mar. Ecol. Prog. Ser. 170, 119-130.

Yukihira, H., Klumpp, D.W., Lucas, J.S., 1998b. Comparative effects of microalgal species and food concentration on suspension feeding and energy budgets of the pearl oysters Pinctada margaritifera and P. maxima (Bivalvia: Pteriidae). Mar. Ecol. Prog. Ser. 171, 7184.

Yukihira, H., Klumpp, D.W., Lucas, J.S., 1999. Feeding adaptations of the pearl oysters Pinctada margaritifera and P. maxima. Mar. Ecol. Prog. Ser. 182, 161-173.

Yukihira, H., Lucas, J.S., Klumpp, D.W., 2000. Comparative effects of temperature on suspension feeding and energy budgets of the pearl oysters Pinctada margaritifera and $P$. maxima. Mar. Ecol. Prog. Ser. 195, 179-188.

Wilbur, K.M., Saleuddin, A.S.M., 1983. The Mollusca. (4): Physiology Part 1. 
473 Wilson, C.A., Beckam, D.W., Dean, J.M., 1987. Calcein as a fluorescent marker of otoliths of $474 \quad$ larval and juvenile fish. T. Am. Fish. Soc. 116, 668-670.

475 Winter, J.E., 1978. Review on knowledge of suspension-feeding in Lamellibranchiate 476 Bivalves, with special reference to artificial aquaculture systems. Aquaculture. 13, 1-33.

477

478

479

480

481

482

483

484

485

486

487

488

489

490

491

492

493

494

495

496

497

498

499 
500 Table 1: Summary of administration techniques, concentrations and immersion times tested 501 for the calcein fluorochrome on Pinctada margaritifera.

502

\begin{tabular}{|c|c|c|c|}
\hline Experiment & $\begin{array}{l}\text { Administration } \\
\text { technique }\end{array}$ & $\begin{array}{l}\text { Concentration } \\
\left(\mathrm{mg} \cdot \mathrm{L}^{-1}\right)\end{array}$ & $\begin{array}{c}\text { Immersion times } \\
\text { (hours) }\end{array}$ \\
\hline \multirow{5}{*}{ Shell marking } & \multirow{3}{*}{ Immersion } & 50 & $6,12,24$ \\
\hline & & 100 & $6,12,24$ \\
\hline & & 150 & $6,12,24$ \\
\hline & \multirow{2}{*}{$\begin{array}{l}\text { Injection into the } \\
\text { palleal cavity }\end{array}$} & 50 & / \\
\hline & & 100 & I \\
\hline \multirow{4}{*}{ Pearl marking } & \multirow{2}{*}{ Immersion } & 150 & 24,43 \\
\hline & & 200 & 24,43 \\
\hline & \multirow{2}{*}{$\begin{array}{c}\text { Injection into the pearl } \\
\text { pouch }\end{array}$} & 150 & l \\
\hline & & 200 & I \\
\hline
\end{tabular}

503

504

505 
506 Figure 1: Location of the sections (1 to 8) and growth areas (anterior, ventral, posterior, dorsal 507 and central) on P. margaritifera shells. White points: located in the prismatic layer; Grey 508 points: located in the nacreous layer.

510 Figure 2: Calcein fluorochrome marks on sections of shell and pearl. Calcein marks are indicated with white arrows. a: Shell ventral side section (x100): transition area between nacreous and prismatic layers of a shell of $P$. margaritifera exposed twice to $150 \mathrm{mg} . \mathrm{L}^{-1}$ calcein by immersion. b: Shell ventral side section (x100): transition area between nacreous and prismatic layers of shell from a 10-month-old P. margaritifera oyster exposed to a 150 mg. $\mathrm{L}^{-1}$ calcein by $24 \mathrm{~h}$ immersion. c: Transversal section of a 4 month-old pearl exposed twice to $200 \mathrm{mg} . \mathrm{L}^{-1}$ by injection into the pearl pouch of P. Margaritifera (x100).

Figure 3: Calcein marking efficiency on shells from 10-month-old P. margaritifera oysters. a: Impact of the calcein administration method: immersion $(\mathrm{N}=70)$; injection into the palleal cavity $(\mathrm{N}=20)$. b: Impact of the calcein concentration: $50 \mathrm{mg} . \mathrm{L}^{-1}(\mathrm{~N}=17) ; 100 \mathrm{mg} . \mathrm{L}^{-1}(\mathrm{~N}=36)$; 150 mg. $\mathrm{L}^{-1}(\mathrm{~N}=17)$. c: Impact of immersion time: $6 \mathrm{~h}(\mathrm{~N}=24) ; 12 \mathrm{~h}(\mathrm{~N}=22) ; 24 \mathrm{~h}(\mathrm{~N}=24)$.

Figure 4: Calcein marking efficiency on $P$. margaritifera pearls. a: Impact of calcein administration method: immersion $(\mathrm{N}=44)$; injection into the pearl pouch $(\mathrm{N}=34)$. b: Impact of the calcein concentration for the injection method: $150 \mathrm{mg} \cdot \mathrm{L}^{-1}(\mathrm{~N}=16) ; 200 \mathrm{mg} \cdot \mathrm{L}^{-1}(\mathrm{~N}=18)$.

Figure 5: Comparison of the nacreous shell deposit rate between calcein marks with respect to the shell area considered $(\mathrm{N}=15)$. Bars indicate standard deviations. Statistical differences are indicated by letters.

Figure 6: Comparison of the deposit rate $\left(\mu \mathrm{m}\right.$. day $\left.^{-1}\right)$ for the ventral (black plot) and dorsal (white plot) sides of the shell according to diet concentrations (cell. $\mathrm{mL}^{-1}$ ) after one and two months of experimentation. Standard deviations are included. Statistical differences between diets are indicated by letters. For any diet, significant differences between the dorsal and ventral sides are marked with an asterisk. 800 cell. $\mathrm{mL}^{-1}$ ventral area: $\mathrm{N}=17$; dorsal area: $\mathrm{N}=11.6000$ cell. $\mathrm{mL}^{-1}$ ventral area: $\mathrm{N}=20$; dorsal area: $\mathrm{N}=16.15000$ cell. $\mathrm{mL}^{-1}$ ventral area: $\mathrm{N}=20$; dorsal area: $\mathrm{N}=15$. 
539 Figure 7: P. margaritifera pearl oyster shell from a low trophic level treatment $\left(800 \mathrm{cell} . \mathrm{mL}^{-1}\right)$ $540(\mathrm{a}, \mathrm{b})$ and a high trophic level treatment $\left(15000 \mathrm{cell}_{\mathrm{mL}}^{-1}\right)(\mathrm{c}, \mathrm{d})$ at an interval of two months. 541 b, c: Aragonite tablets deposited immediately after staining. a, d: Aragonite tablets deposited 542 two months later.

543

544 Figure 8: Comparison of the pearl deposit rate $\left(\mu\right.$ m.day $\left.{ }^{-1}\right)$ for 4-month-old and 24-month-old 545 pearls. 4-month-old pearls: $\mathrm{N}=5$; 24-month-old pearls: $\mathrm{N}=4$. Bars indicate standard deviation. 


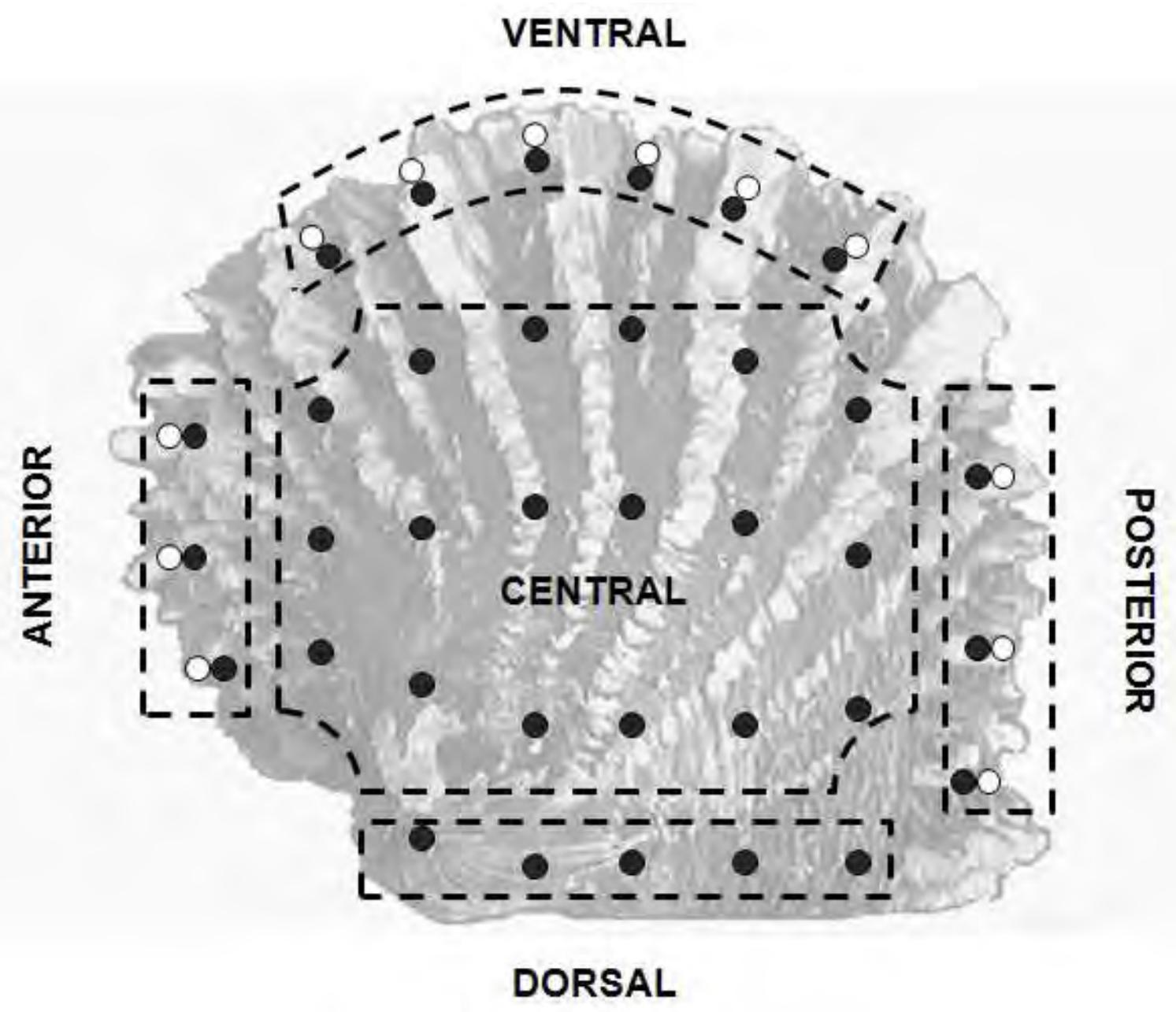

$\begin{array}{lrlllllll} & \uparrow & \uparrow & \uparrow & \uparrow & \uparrow & \uparrow & \uparrow & \uparrow \\ \text { Sections } & 1 & 2 & 3 & 4 & 5 & 6 & 7 & 8\end{array}$ 
551

552

553

554

555
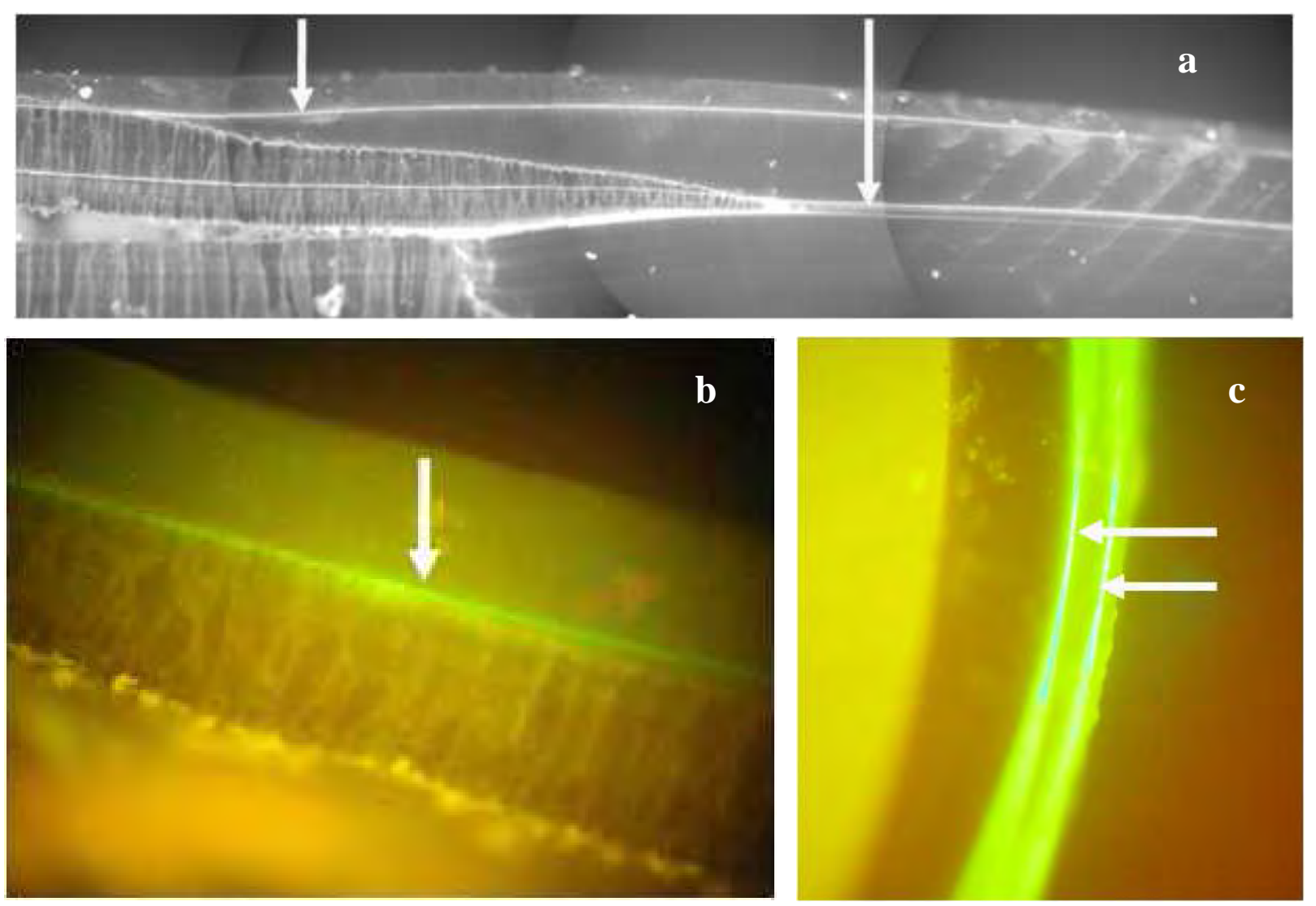

556

Figure 2

557 


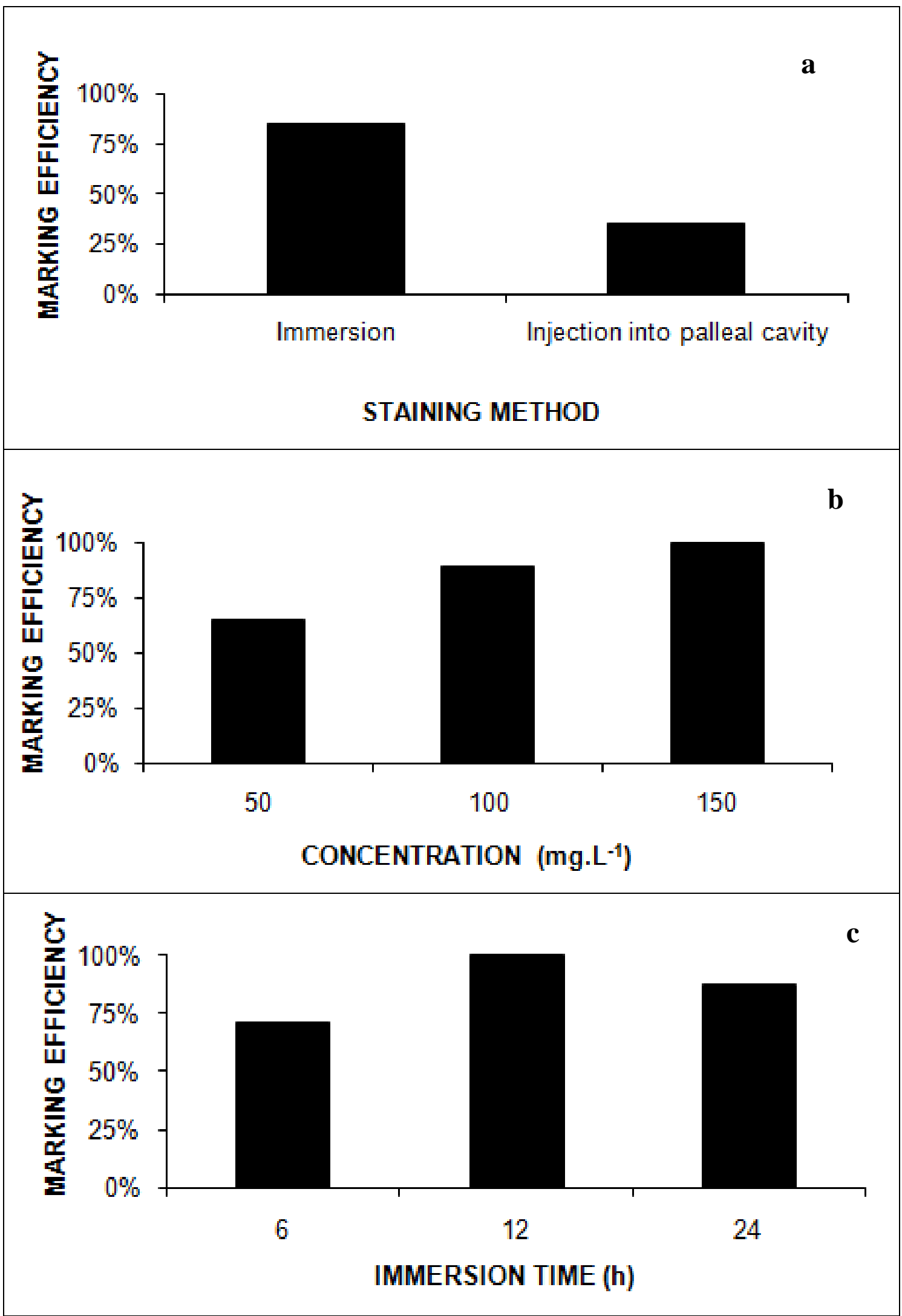

Figure 3 


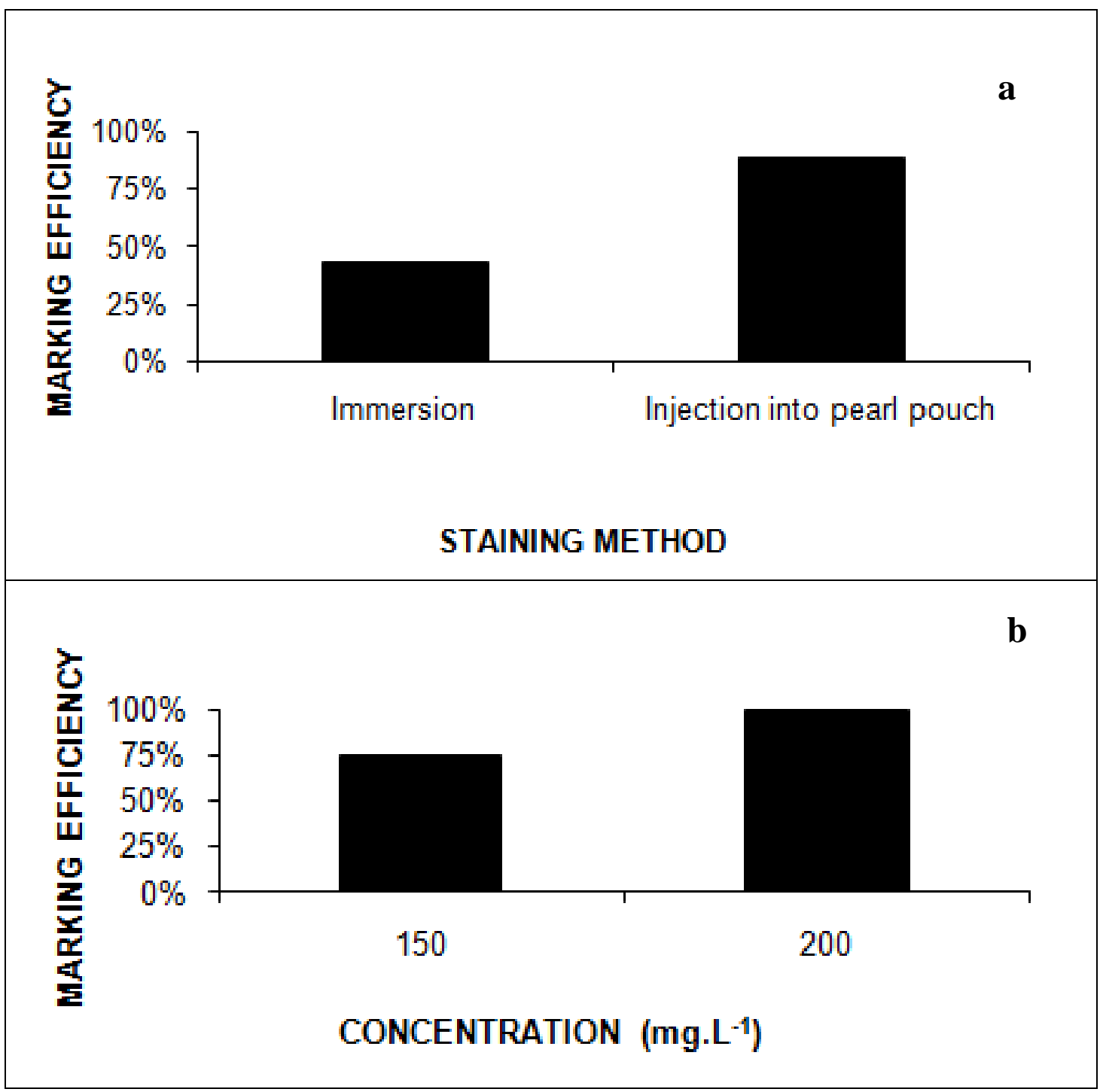

561

562

$\underline{\text { Figure } 4}$ 
563

564

565

566

567

568

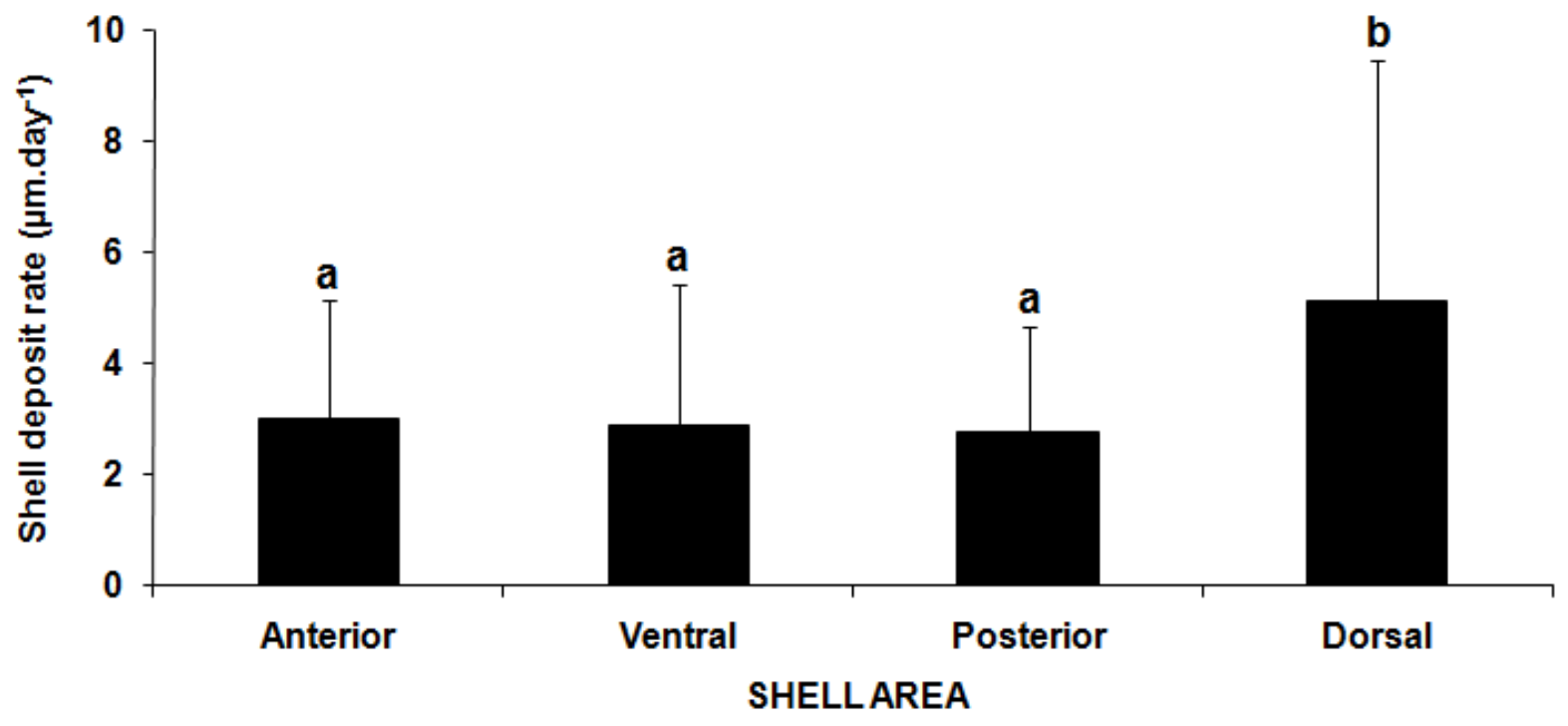

569

570

571

572

573

Figure 5 
573

574

575

576

577

578

579

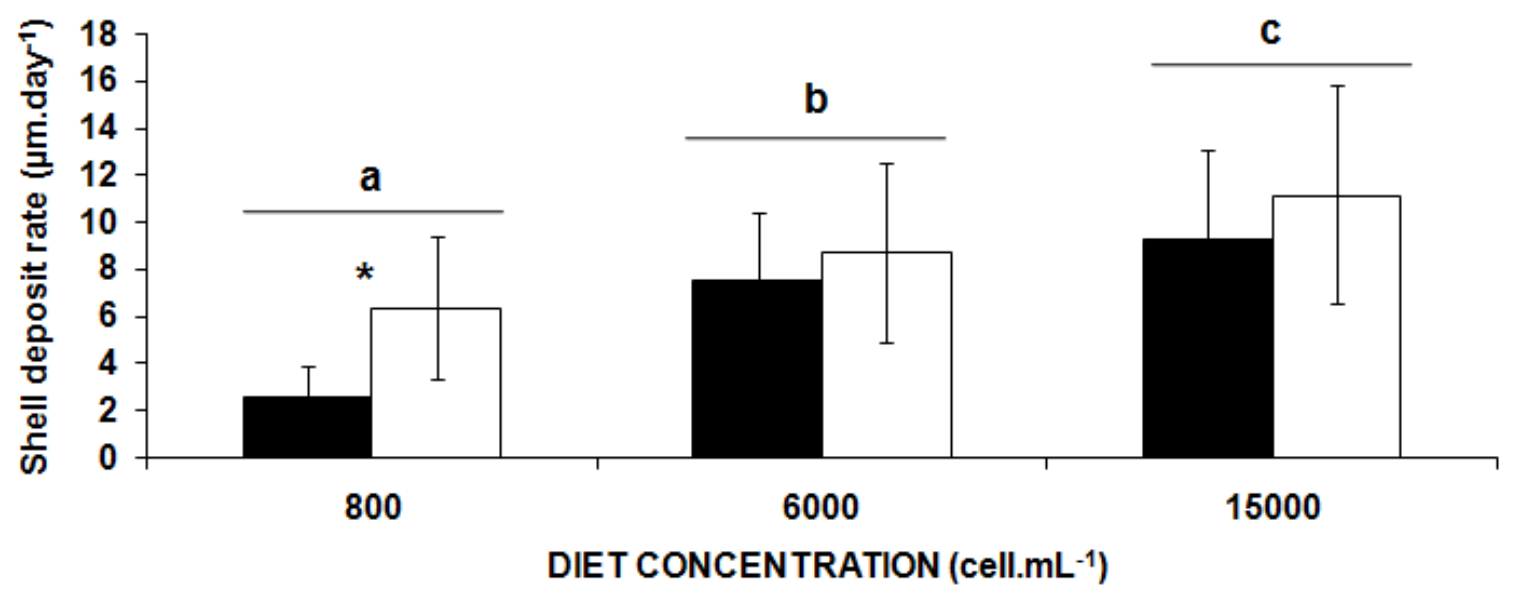

580

581

Figure 6

582

583 

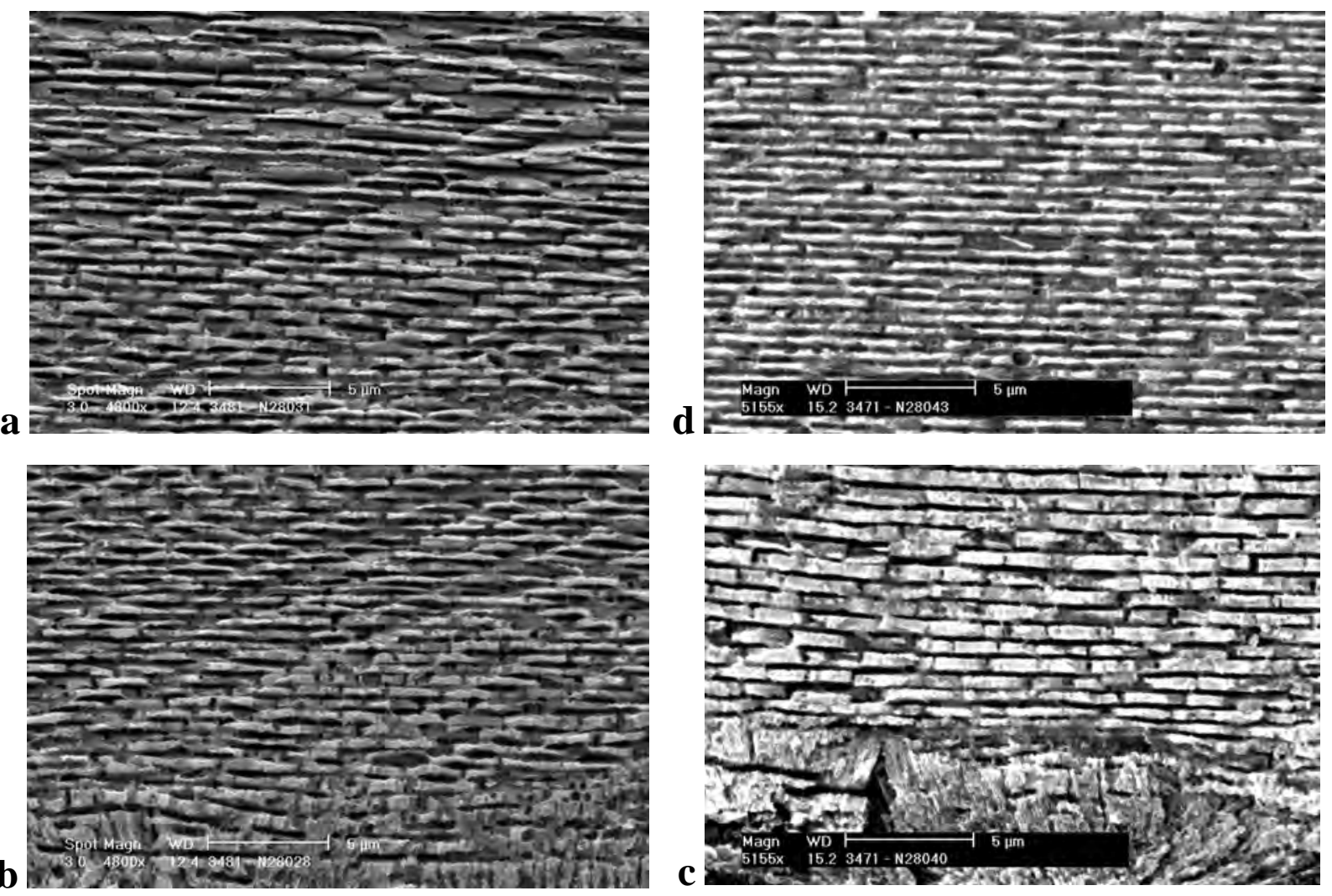
590

591

592

593

594

595

596

597

598

599

600

601

602

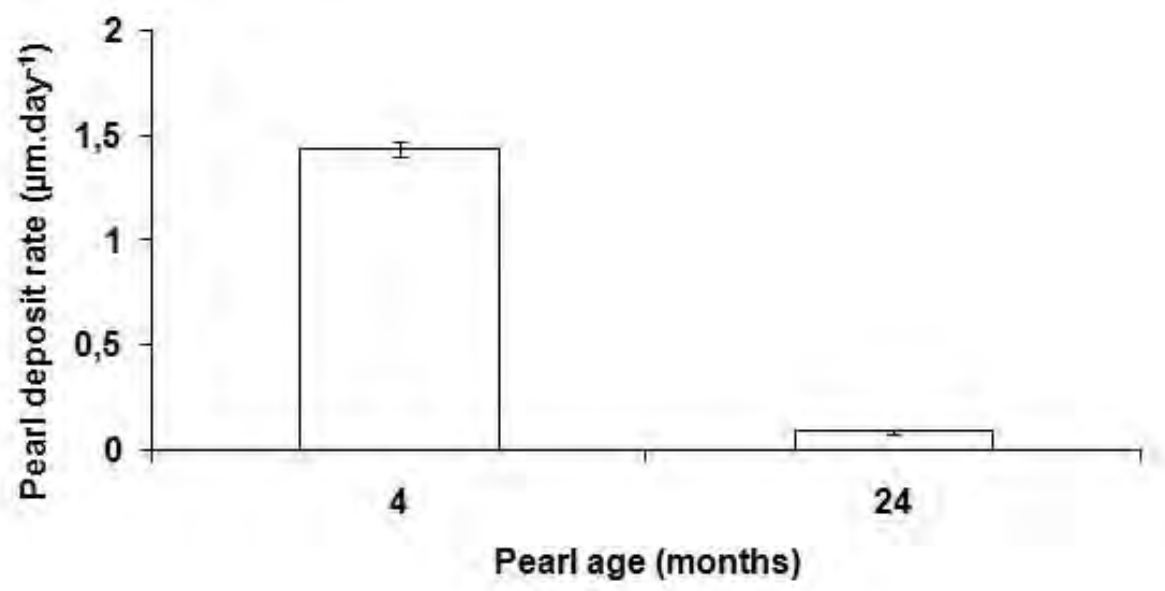

Figure 8 
602

603

604

605 